\title{
Reduced membranous $\beta$-catenin protein expression is associated with metastasis and poor prognosis in squamous cell carcinoma of the esophagus
}

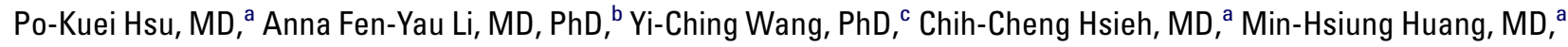 \\ Wen-Hu Hsu, MD, and Han-Shui Hsu, MD, PhDa
}

From the Division of Thoracic Surgery, Department of Surgery, and the Department of Pathology, ${ }^{\text {b }}$ Taipei Veterans General Hospital, National Yang-Ming University, School of Medicine, Taipei, Taiwan; and the Department of Pharmacology, College of Medicine, ${ }^{\mathrm{c}}$ National Cheng Kung University, Tainan, Taiwan.

Received for publication July 10, 2007; revisions received Aug 29, 2007; accepted for publication Nov 9, 2007.

Address for reprints: Han-Shui Hsu, MD, $\mathrm{PhD}$, Division of Thoracic Surgery, Department of Surgery, Taipei Veterans General Hospital, No. 201, Sec. 2, Shih-Pai Road, Taipei, Taiwan (E-mail: hsuhs@vghtpe. gov.tw).

J Thorac Cardiovasc Surg 2008;135:1029-35 $0022-5223 / \$ 34.00$

Copyright $\odot 2008$ by The American Association for Thoracic Surgery

doi:10.1016/j.jtcvs.2007.11.007
Objectives: The aim of this study was to evaluate, by immunohistochemical analysis, the protein expression of $\beta$-catenin and p53 in resected esophageal squamous cell carcinoma specimens. The clinical relevance and prognostic significance of the expression of these proteins were also analyzed.

Methods: Immunohistochemistry was performed on paraffin-embedded tissue specimens from 68 resected esophageal squamous cell carcinoma tumor specimens to detect the expression of $\beta$-catenin and p53. The correlation between the results of immunoexpression and the clinicopathologic parameters and patient survival was processed statistically.

Results: Reduced membranous $\beta$-catenin expression was noted in $43(63.2 \%)$ of 68 tumor specimens. Increased expression of p53 was observed in $43(63.2 \%)$ of 68 specimens. Reduced membranous $\beta$-catenin protein expression was associated with the presence of distant metastasis $(P=.006)$. Patients with reduced membranous $\beta$-catenin expression had a worse prognosis than patients with normal membranous $\beta$-catenin expression $(P=.005)$. Patients with combined increased p53 and reduced membranous $\beta$-catenin protein expression had the worst prognosis $(P=.012)$. In a multivariate survival analysis, reduced membranous $\beta$-catenin expression and nodal involvement were independent prognostic factors $(P=.004$ and .019 , respectively).

Conclusions: Immunohistochemical analysis revealed that reduced membranous $\beta$-catenin protein expression was associated with the presence of distant metastasis and a poor prognosis in patients with esophageal squamous cell carcinoma. Combined increased $\mathrm{p} 53$ and reduced membranous $\beta$-catenin protein expression indicated a very poor prognosis in patients with esophageal squamous cell carcinoma. Further investigation is needed to understand the roles of $\beta$-catenin and p53 in the tumorigenesis and metastasis of esophageal squamous cell carcinoma.

$\mathrm{E}$ sophageal squamous cell carcinoma (ESCC) is associated with poor patient survival despite aggressive treatments. The 5-year survival in patients with ESCC is usually approximately $20 \%$ to $25 \%$ after standard esophagectomy. Many clinicopathologic variables, including the tumor invasion depth, the lymph node involvement, lymphovascular invasion, and distant metastasis, have been examined in patients with ESCC as aids to predict the prognosis. ${ }^{1}$ Some molecular changes have also been investigated to elucidate the tumorigenesis of ESCC. Recently, $\beta$-catenin has drawn much attention because its connection to tumorigenesis has been reported in many types of gastrointestinal cancers, including colorectal, gastric, and esophageal cancers. ${ }^{2}$ The multifunctional $\beta$-catenin plays crucial roles in signal transduction and maintenance of cell-cell adhesion. ${ }^{3,4}$ Under normal circumstances, the cytoplasmic $\beta$-catenin level is kept low through a large multiprotein destruction complex. Within this complex, $\beta$-catenin is phosphorylated by casein kinase $\mathrm{I} \alpha / \mathrm{gly}$ cogen synthase kinase $3 \beta$ (GSK3 $\beta$ ), ubiquitinated by $\beta$-transducin-repeat-containing protein, and subsequently degraded in proteasomes. ${ }^{5}$ Either $\beta$-catenin gene mutation 


\section{Abbreviations and Acronyms}

ESCC = esophageal squamous cell carcinoma

GSK $3 \beta=$ glycogen synthase kinase $3 \beta$

or dysfunction of the destruction complex may lead to accumulation of cytoplasmic $\beta$-catenin. Should $\beta$-catenin inappropriately enter the nucleus, it forms a complex with $\mathrm{T}$ cell-specific factor/lymphoid enhancer binding factor protein and activates aberrant transcription after binding to DNA. ${ }^{3-5}$ In addition, $\beta$-catenin also links E-cadherin at the cell membrane and associates with the actin cytoskeleton through $\alpha$ catenin. ${ }^{6}$ In a multi-institutional study enrolling 416 patients with ESCC, the investigators found that loss of E-cadherin expression was associated with a poor prognosis in patients with ESCC. ${ }^{7}$ Reduced membranous $\beta$-catenin expression may also downregulate the E-cadherin-catenin complex, which may disrupt the integrity of cell architecture and contribute to enhanced tumor cell migration, leading to invasion and metastasis. ${ }^{3,8}$ Deregulated $\beta$-catenin, either increased cytoplasmic levels or reduced membranous levels, would contribute to tumorigenesis by inappropriate transcription of target genes and the loss of cell-cell adhesion. ${ }^{9}$

A possible cross-talk between the $\beta$-catenin and p53 pathways during cancer progression has long been suggested, most notably in human colorectal cancers. ${ }^{10,11}$ Activation of p53 occurs in response to a stress signal and leads to either cell cycle arrest or cellular apoptosis. ${ }^{11}$ The functional p53 protein safeguards against deregulated cells by eliminating cells with damaged genomes as well as facilitating the repair of such damage. ${ }^{12}$ Authors of some studies have demonstrated that $\beta$-catenin levels can induce the p14ARF gene, which negatively regulates MDM2 and results in higher p53 levels. ${ }^{10,11}$ An activated p53 protein, in turn, positively regulates the transcription of Siah, Axin, and GSK3 $\beta$ proteins, which subsequently act to degrade the $\beta$-catenin protein. ${ }^{13-15}$

There are few studies in the literature in which the relationship between $\beta$-catenin and $\mathrm{p} 53$ protein expression in ESCC is investigated. In this study, we evaluated the protein expression of $\beta$-catenin and p53 in resected ESCC specimens by using immunohistochemical analysis. The clinical relevance and prognostic significance of these protein expressions were also analyzed.

\section{Patients and Methods Patients}

Tumor specimens were obtained from 68 patients with ESCC who underwent subtotal esophagectomy and reconstruction through a retrosternal approach between 1996 and 2000 at Taipei Veterans General Hospital. There were 2 women and 66 men. The mean age was 65 years (range 36-83 years). None of these patients received chemotherapy or radiotherapy preoperatively. The patho- logic tumor stage was determined according to the TNM classification. ${ }^{16}$ The clinicopathologic data, including gender, age, depth of tumor invasion, lymph node involvement, and presence of distant metastasis, were collected retrospectively. Postoperative adjuvant therapy was given in patients with lymph node metastasis or in patients who were found to have tumor recurrence or metastasis during the follow-up period. The survival data were obtained from the Cancer Registry Database in the Taipei Veterans General Hospital. Overall patient survival, defined as the time from operation to death, was used as a measure of prognosis. This study was approved by the Institutional Review Board in the Taipei Veterans General Hospital.

\section{Immunohistochemical Staining}

Immunohistochemical staining was performed on 3- $\mu$ m-thick sections of formalin-fixed, paraffin-embedded tissue. After deparaffinization and rehydration, all sections were treated with microwaves in $10 \mathrm{mmol} / \mathrm{L}$ citrate buffer ( $\mathrm{pH} 6.0$ ) for 10 minutes at $121^{\circ} \mathrm{C}$ for antigen retrieval. To block endogenous peroxidase activity, we immersed the sections in serum for 10 minutes. Then all sections were incubated at $4^{\circ} \mathrm{C}$ overnight with the following antibodies: mouse monoclonal antibody to $\beta$-catenin (1:100; Transduction Laboratories, Lexington, Ky) and monoclonal antibody DO-7 (1:150; DAKO, Glostrup, Denmark), which recognizes both wild-type and mutant-type p53 proteins. Monoclonal antibody Ab-5 (1:20; Oncogene, Boston, Mass), which recognizes only wild-type p53 protein, was also used to clarify the type of overexpressed p53. Color reaction was performed by the labeled streptavidin biotin technique with 3,3'-diaminobenzidine as a chromogen (LSAB + kit, HRP; DAKO). Tissues were counterstained with hematoxylin and then dehydrated. Adjacent normal esophageal epithelium was used as the internal control.

Evaluation of the immunohistochemical staining was conducted by a pathologist who had no knowledge of the clinical characteristics of the patients. The expression was scored as 3 if more than $75 \%$ of tumor cells were immunostained positive, as 2 if $25 \%$ to $75 \%$ of cells were positive, as 1 if less than $25 \%$ of cells were positive, and as 0 if less than $5 \%$ were positive. The normal esophageal epithelium was positively stained by $\beta$-catenin at the cell membrane but negative for $\beta$-catenin in the cytoplasm and negative for $\mathrm{p} 53 /$ DO-7 in the nucleus. On the basis of the normal epithelium expression, the membranous $\beta$-catenin expression was defined as reduced if the score was 0,1 , or 2 and normal if the score was 3 . Cytoplasmic $\beta$-catenin expression was defined as increased if the score was 2 or 3 and normal if the score was 0 or 1 . Four typical $\beta$-catenin expression patterns were described and are shown in Figure 1. The p53 expression was defined as normal if the score was 0 or 1 and increased if the score was 2 or 3 . In the study, the p53 (Ab-5) antibody was positively stained at the basal proliferative layer of normal esophageal epithelium only, reflecting its role as cell cycle checkpoints at G1 and G2 phase. The positive stain at the basal layer of normal esophageal epithelium served as internal control.

\section{Statistical Analyses}

The correlations between immunohistochemical results and clinicopathologic variables were analyzed by $\chi^{2}$ test. Survival curves were estimated by the Kaplan-Meier method and compared by the logrank test. Multivariate analysis was performed by the Cox regression model. Covariates were selected in a stepwise fashion with 

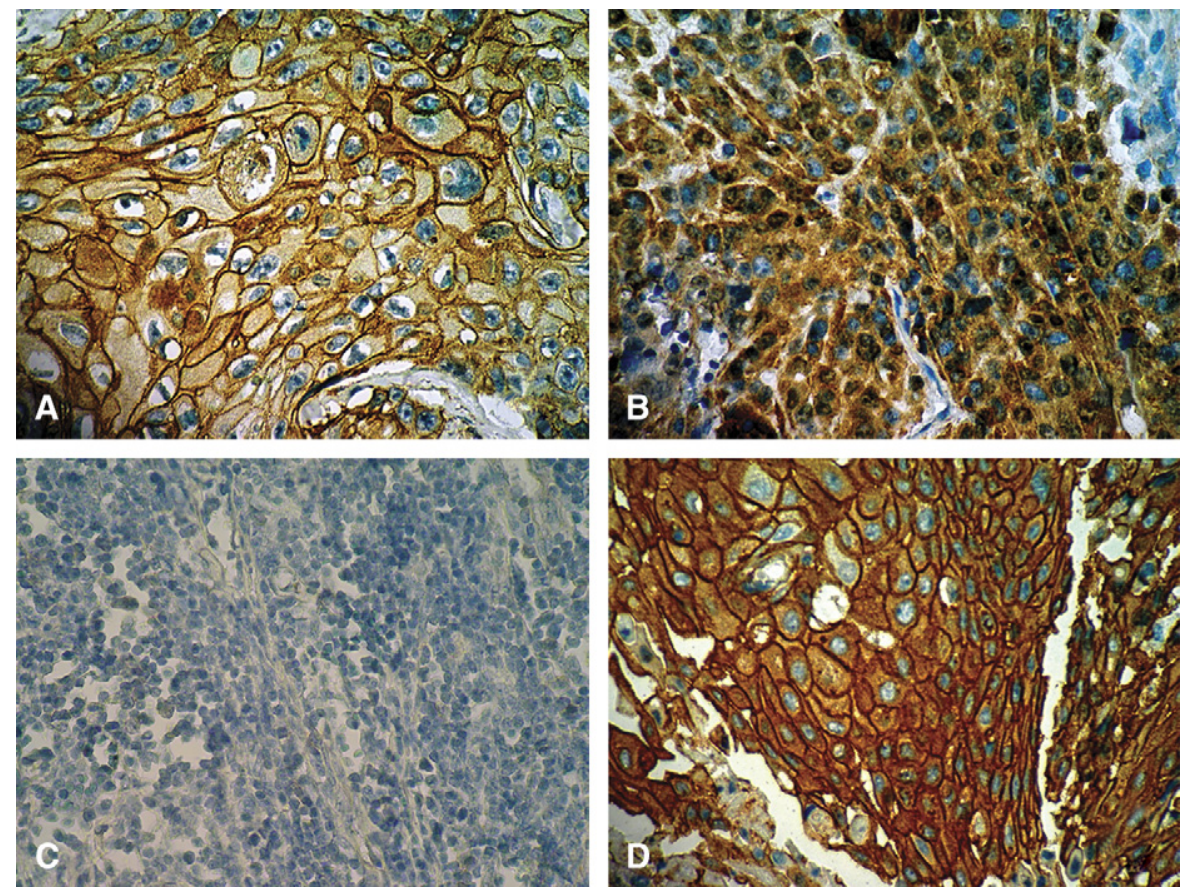

Figure 1. Immunohistochemical staining patterns of $\beta$-catenin in ESCC (original magnification $\times 400$ ). A, Preserved $\beta$-catenin staining at the cell membrane and normal staining in the cytoplasm. $B$, Reduced staining at the cell membrane and increased $\beta$-catenin staining in the cytoplasm. $\quad \mathrm{C}$, Reduced $\beta$-catenin staining at the cell membrane and no staining in the cytoplasm. D, Preserved $\beta$-catenin staining at the cell membrane and increased staining in the cytoplasm.
Backward:Ward method. All calculations were performed with SPSS 13.0 software (SPSS, Inc, Chicago, Ill).

\section{Results}

Table 1 shows the demographic data and the results of survival analysis in 68 patients with ESCC. The 5-year survival was $23.5 \%$, with a median survival of 20 months. Reduced membranous $\beta$-catenin expression was noted in $43(63.2 \%)$ of 68 tumor specimens. Increased expression of cytoplasmic $\beta$-catenin was noted in $15(22.1 \%)$ of 68 specimens. Increased protein expression of p53/DO-7 was observed in $43(63.2 \%)$ of 68 specimens. None of the specimens stained positively for wild-type p53 (Ab-5). In the survival analysis, nodal involvement and distant metastasis were associated with poor prognosis ( $P=.032$ and .013 , respectively). Patients with reduced membranous $\beta$-catenin expression had a worse prognosis than patients with normal membranous $\beta$-catenin expression (Figure $2, P=.005$ ). Patients with increased p53 expression also had a worse prognosis; however, the difference did not reach statistical significance. In the combined analysis of membranous $\beta$-catenin and p53 protein expression in the prognostic significance of patients with ESCC, we observed that patients with increased p53 and reduced membranous $\beta$-catenin protein expression had the worst prognosis (Figure 3, $P=.012$ ). Table 2 showed that there was no significant correlation between $\mathrm{p} 53$ and membranous or cytoplasmic $\beta$-catenin protein expression in ESCC specimens. Table 3 shows the relationship between the clinicopathologic parameters and the immunohistochem- ical staining results. The results showed that reduced membranous $\beta$-catenin expression was associated with the presence of distant metastasis $(P=.006)$. There was no relationship between cytoplasmic $\beta$-catenin expression and any $\mathrm{T}, \mathrm{N}$, or $\mathrm{M}$ factors. The increased p53 protein expression correlated with lymph node involvement $(P=.047)$. In multivariate survival analysis, reduced membranous $\beta$-catenin expression and nodal involvement were independent prognostic factors (Table 4, $P=.004$ and .019 , respectively).

\section{Discussion}

In the present study, we showed for the first time, using immunohistochemical analysis, that reduced membranous $\beta$-catenin protein expression is associated with distant metastasis and poor prognosis and that combined increased p53 and reduced membranous $\beta$-catenin protein expression are indicative of a very poor prognosis in patients with ESCC. In our study, $63.2 \%$ of tumor specimens had reduced $\beta$-catenin staining in the cell membrane, which is compatible with some previous reports in the literature. ${ }^{17-22}$ In contrast to our study, Castro, ${ }^{17}$ Nair, ${ }^{18}$ and their colleagues found no correlation between membranous $\beta$-catenin expression and any clinicopathologic features including tumor grade and patient survival. In Japan, Takayama, ${ }^{19}$ Nakanishi, ${ }^{20}$ and their associates reported that although downregulation of membranous $\beta$-catenin was associated with poor tumor differentiation, membranous $\beta$-catenin expression did not have prognostic significance in ESCC. In another study by Takayama and coworkers, ${ }^{21}$ reduction in membranous $\beta$-catenin expression 
TABLE 1. Patient demographics and univariate survival analysis results

\begin{tabular}{|c|c|c|c|c|}
\hline Variable & No. $(\%)$ & Median survival (mo) & Five-year survival (\%) & $P$ value \\
\hline Age & & & & .508 \\
\hline$\leq 65$ years of age & $32(47.1)$ & $23.00 \pm 7.01$ & 25.0 & \\
\hline$>65$ years of age & $36(52.9)$ & $14.00 \pm 6.60$ & 22.2 & \\
\hline Sex & & & & .420 \\
\hline Male & $66(97.1)$ & $20.00 \pm 4.5$ & 22.7 & \\
\hline Female & $2(2.9)$ & - & - & \\
\hline Tumor invasion depth (T) & & & & .142 \\
\hline $\mathrm{T} 1 / 2$ & $19(27.9)$ & $36.00 \pm 7.98$ & 36.8 & \\
\hline $\mathrm{T} 3 / 4$ & $49(72.1)$ & $15.00 \pm 4.08$ & 18.4 & \\
\hline Nodal involvement (N) & & & & $.032^{*}$ \\
\hline No & $25(36.8)$ & $29.00 \pm 10.00$ & 40.0 & \\
\hline N1 & $43(63.2)$ & $15.00 \pm 2.18$ & 14.0 & \\
\hline Distant metastasis (M) & & & & $.013^{*}$ \\
\hline Mo & $57(83.8)$ & $24.00 \pm 3.78$ & 26.3 & \\
\hline M1 & $11(16.2)$ & $11.00 \pm 1.65$ & 9.1 & \\
\hline Membranous $\beta$-catenin & & & & $.005^{*}$ \\
\hline Normal & $25(36.8)$ & $32.00 \pm 15.00$ & 40.0 & \\
\hline Reduced & $43(63.2)$ & $14.00 \pm 2.73$ & 14.0 & \\
\hline Cytoplasmic $\beta$-catenin & & & & .821 \\
\hline Normal & $53(77.9)$ & $20.00 \pm 4.68$ & 24.5 & \\
\hline Increased & $15(22.1)$ & $24.00 \pm 8.373$ & 20.0 & \\
\hline p53 & & & & .276 \\
\hline Normal & $25(36.8)$ & $32.00 \pm 6.50$ & 32.0 & \\
\hline Increased & $43(63.2)$ & $15.00 \pm 1.87$ & 18.6 & \\
\hline \multicolumn{5}{|c|}{ Combined $\mathrm{p} 53$ and membranous $\beta$-catenin } \\
\hline Normal p53 and normal $\beta$-catenin & $11(16.2)$ & $55.00 \pm 21.47$ & 45.5 & $.012^{*}$ \\
\hline Increased p53 or reduced $\beta$-catenin & $28(41.2)$ & $29.00 \pm 5.94$ & 28.6 & \\
\hline Increased p53 \& reduced $\beta$-catenin & $29(42.6)$ & $13.00 \pm 2.02$ & 10.3 & \\
\hline
\end{tabular}

Median survival time is presented as an estimate \pm standard error of the mean. ${ }^{*} A P$ value $<.05$ was considered significant by log-rank test.

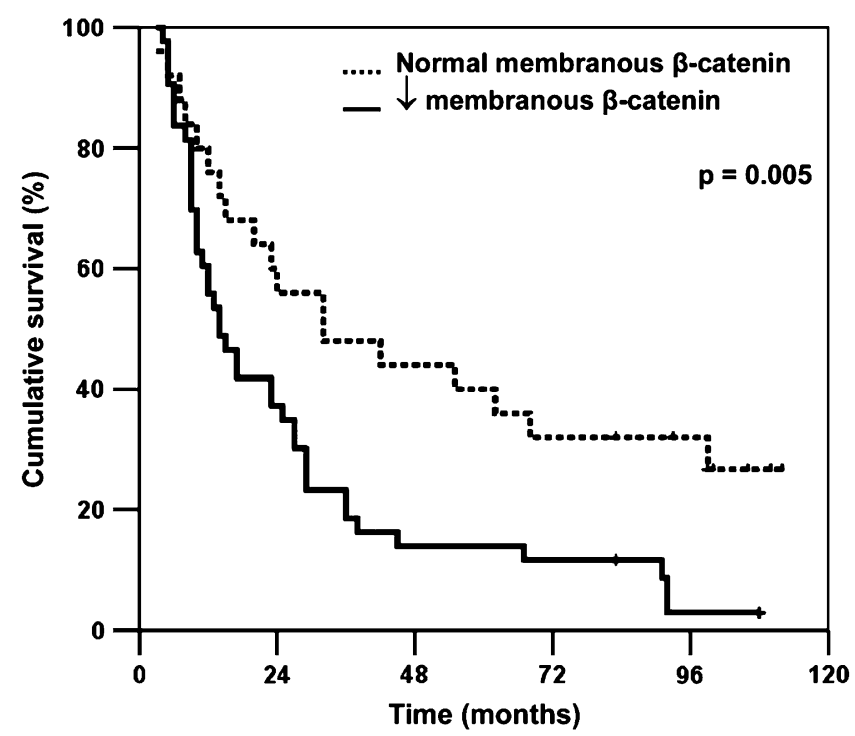

Figure 2. The Kaplan-Meier survival curve for protein expression of membranous $\beta$-catenin, indicating that patients with reduced membranous $\beta$-catenin protein expression had a poor prognosis ( $\log$-rank test, $P=.005)$. was associated with the depth of tumor invasion and lymph node involvement. In China, Zhao and colleagues ${ }^{22}$ reported that there was a correlation between membranous $\beta$-catenin expression and tumor histologic grade. Patients harboring tumors with low membranous $\beta$-catenin expression had shorter survival times than those with higher expression, but the difference did not reach statistical significance in that study. In our study, all 11 patients with distant metastasis had reduced membranous $\beta$-catenin expression. In contrast, none of patients with normal membranous $\beta$-catenin expression had distant metastasis. In a multivariate survival analysis, reduced membranous $\beta$-catenin expression was also an independent prognostic factor.

A possible explanation for the correlation between reduced membranous $\beta$-catenin expression and distant metastasis may be disruption of cell-cell junction integrity. The metastasis cascade includes steps of local invasion, intravasation, extravasation, and re-establishment at distant organs. ${ }^{23}$ In the initial steps of local invasion and intravasation, the cancer cells undergo the epithelial-mesenchymal transition, which is a process that stable cell-cell and cell-matrix interaction was lost, and the tumor invasiveness was increased. ${ }^{24}$ 


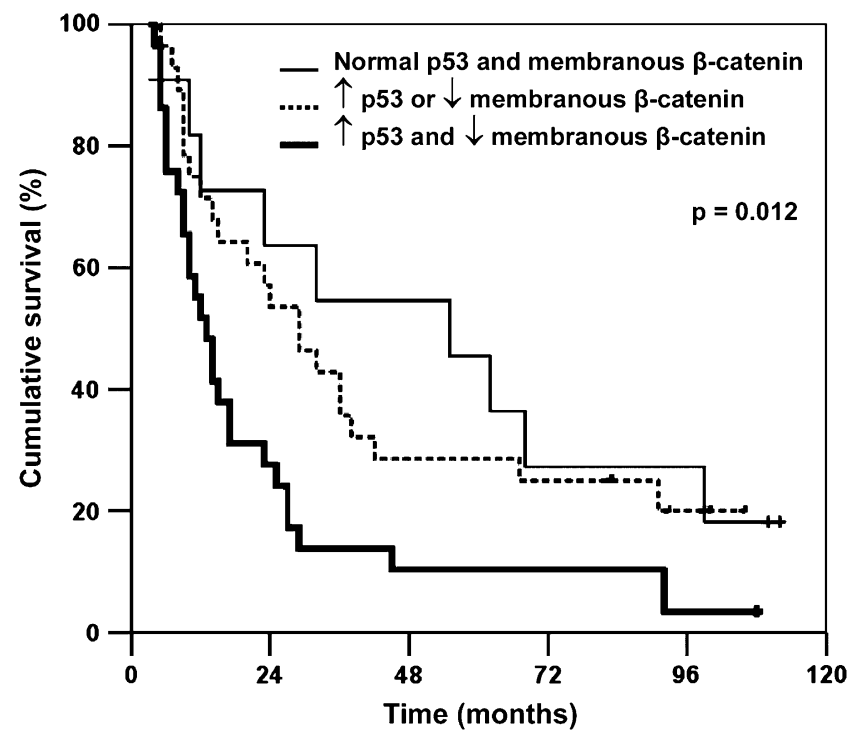

Figure 3. The Kaplan-Meier survival curve for protein expression of $\mathrm{p} 53$ and membranous $\beta$-catenin, showing that combined increased p53 expression and reduced $\beta$-catenin expression was associated with a poor prognosis $(\log -$ rank test, $P=.012)$.

The hallmark of epithelial-mesenchymal transition is the loss of the adherens junction, which consists of $\beta$-catenin and E-cadherin (E-cadherin-catenin complex). ${ }^{25}$ Following the logic of this theory, it is intuitive that reduced membranous $\beta$-catenin expression causes the dysfunction of the E-cadherin-catenin complex, promotion of cancer cell detachment from primary site, and facilitation of cancer cell dissemination. The results of our study indicated that membranous $\beta$-catenin is important in maintaining the cell-cell junction in ESCC and that loss of membranous $\beta$-catenin may contribute to enhanced tumor metastasis.

Cytoplasmic $\beta$-catenin is a member of the WNT pathway, which had been investigated extensively in colorectal carci-
TABLE 2. Relationship between p53 and $\beta$-catenin expression in the cell membrane and cytoplasm

\begin{tabular}{lccc}
\hline & \multicolumn{2}{c}{ p53 } & \\
\cline { 2 - 3 } & Normal & Increased & P value \\
\hline Membranous $\beta$-catenin & & & .345 \\
$\quad$ Reduced & 14 & 29 & \\
$\quad$ Normal & 11 & 14 & \\
$\begin{array}{l}\text { Cytoplasmic } \beta \text {-catenin } \\
\quad \text { Increased }\end{array}$ & 6 & 9 & .768 \\
$\quad$ Normal & 19 & 34 & \\
\hline
\end{tabular}

nogenesis ${ }^{2-5}$; however, its role in ESCC tumorigenesis is less clear. Authors of previous works have reported that increased cytoplasmic $\beta$-catenin expression was found in approximately $18 \%$ to $68 \%$ of ESCC. ${ }^{17,26,27}$ In the study by Zhang and colleagues, ${ }^{26}$ which included 44 patients with ESCC, the authors observed that increased cytoplasmic $\beta$-catenin expression was associated with lymph node metastasis. In another study, Shiozaki and associates ${ }^{27}$ showed that patients with increased cytoplasmic $\beta$-catenin expression had worse prognoses; however, in multivariate analysis, cytoplasmic $\beta$-catenin expression was not an independent significant prognostic factor in ESCC. In our study, increased cytoplasmic $\beta$-catenin was noted in $22.1 \%$ of ESCC tumor specimens. Cytoplasmic $\beta$-catenin protein expression was not associated with any clinicopathologic parameters or patient survival.

The clinical significance of p53 protein expression in ESCC is controversial. In our study, increased p53 expression was observed in $63.2 \%$ of ESCC tumor specimens and was associated with the nodal involvement. Although patients with increased p53 expression have a worse prognosis than those with normal p53 expression, the difference did not reach statistical significance. Some in vitro studies have revealed cross-talk between $\beta$-catenin and $\mathrm{p} 53$. Accumulation of $\beta$-catenin can serve as a stimulus for activation of p53

TABLE 3. Relationship between clinicopathologic features and immunohistochemical staining results

\begin{tabular}{|c|c|c|c|c|c|c|c|c|c|}
\hline & \multicolumn{3}{|c|}{ Membranous $\beta$-catenin } & \multicolumn{3}{|c|}{ Cytoplasmic $\beta$-catenin } & \multicolumn{3}{|c|}{ p53 } \\
\hline & Reduced & Normal & $P$ value & Normal & Increased & $P$ value & Normal & Increased & $P$ value \\
\hline $\mathrm{T}$ & & & .094 & & & .901 & & & .570 \\
\hline $\mathrm{T} 1 / 2$ & 15 & 4 & & 15 & 4 & & 8 & 11 & \\
\hline $\mathrm{T} 3 / 4$ & 28 & 21 & & 38 & 11 & & 17 & 32 & \\
\hline $\mathrm{N}$ & & & .534 & & & .768 & & & $.047^{*}$ \\
\hline No & 17 & 8 & & 19 & 6 & & 13 & 12 & \\
\hline N1 & 26 & 17 & & 34 & 9 & & 12 & 31 & \\
\hline M & & & $.006^{*}$ & & & .257 & & & .163 \\
\hline Mo & 32 & 25 & & 43 & 14 & & 23 & 34 & \\
\hline M1 & 11 & 0 & & 10 & 1 & & 2 & 9 & \\
\hline Total & 43 & 25 & & 53 & 15 & & 25 & 43 & \\
\hline
\end{tabular}

$T$, Tumor invasion depth; $N$, nodal involvement; $M$, distant metastasis. ${ }^{*}$ A $P$ value $<.05$ was considered significant by $\chi^{2}$ test. 
TABLE 4. Multivariate survival analysis results

\begin{tabular}{lccc}
\hline \multicolumn{1}{c}{ Variable } & Hazard ratio & 95\% Cl & $\boldsymbol{P}$ value \\
\hline $\begin{array}{l}\text { Tumor invasion depth } \\
\text { T1/2 }\end{array}$ & 1.00 & - & .262 \\
T3/4 & 1.45 & $0.752-2.845$ & \\
Lymph node involvement & & & $.019^{*}$ \\
N0 & 1.00 & - & \\
N1 & 1.96 & $1.118-3.423$ & \\
Distant metastasis & & & .203 \\
M0 & 1.00 & - & \\
M1 & 1.58 & $0.780-3.209$ & \\
Membranous $\beta$-catenin & & & $.004^{*}$ \\
$\quad$ Normal & 1.00 & - & \\
Reduced & 2.31 & $1.307-4.101$ & \\
p53 & & & .517 \\
$\quad$ Normal & 1.00 & - & \\
$\quad$ Increased & 1.20 & $0.094-2.065$ & \\
\hline
\end{tabular}

Multivariate analysis was performed by the Cox regression model. Covariates were selected in a stepwise fashion with the Backward:Ward method. Probability for stepwise was .05 for entry and .10 for removal, respectively. $\mathrm{Cl}$, Confidence interval. ${ }^{*} \mathrm{~A} P$ value $<.05$ was considered significant.

through interaction with p14ARF and MDM2. ${ }^{10,11}$ On the other hand, activated p53 is able to enhance the expression of Siah, Axin, and GSK $3 \beta$ proteins, which mediate the degradation of the $\beta$-catenin protein. ${ }^{13-15}$ In one study based on the Drosophila eye disc model, Yamaguchi and colleagues ${ }^{28}$ observed that mutation of the Armadillo (Drosophila $\beta$-catenin) gene, which is essential for adherens junctions integrity, leads to enhancement of p53-induced apoptosis, suggesting that abnormality at the adherens junction is a signal for $\mathrm{p} 53$ activation and activated p53 consequently induces apoptosis to remove abnormal cells from tissue. These interactions between $\beta$-catenin and p53, however, could not be confirmed by immunohistochemistry methods in human cancers. In hepatocellular carcinoma, Torbenson and associates ${ }^{29}$ found no association between cytoplasmic $\beta$-catenin and p53 expression. In lung adenocarcinoma, Nozawa and colleagues ${ }^{30}$ concluded that there was no association between membranous $\beta$-catenin and $\mathrm{p} 53$ expression. The relationship between $\beta$-catenin and $\mathrm{p} 53$ has never been evaluated in ESCC. In this study, we found no correlation between $\beta$-catenin and p53 expression by using immunohistochemical methods; however, we did show for the first time that combined increased p53 and reduced membranous $\beta$-catenin expression indicated a very poor prognosis in ESCC. Further study to elucidate the relationship between membranous $\beta$-catenin and $\mathrm{p} 53$ protein expression may be mandatory.

In conclusion, using immunohistochemical analysis, we found that reduced membranous $\beta$-catenin protein expression was associated with the presence of distant metastasis and poor prognosis in ESCC. Combined increased p53 and reduced membranous $\beta$-catenin protein expression indicated a very poor prognosis in patients with ESCC. Further investigation is needed to understand the roles of $\beta$-catenin and p53 in the tumorigenesis and metastasis of ESCC.

\section{References}

1. Fahn HJ, Wang LS, Huang BS, Huang MH, Chien KY. Tumor recurrence in long-term survivors after treatment of carcinoma of the esophagus. Ann Thorac Surg. 1994;57:677-81.

2. Doucas H, Garcea G, Neal CP, Manson MM, Berry DP. Changes in the Wnt signaling pathway in gastrointestinal cancers and their prognostic significance. Eur J Cancer. 2005;41:365-79.

3. Nelson WJ, Nusse R. Convergence of Wnt, $\beta$-catenin, and cadherin pathways. Science. 2004;303:1483-7.

4. Ilyas M. Wnt signalling and the mechanistic basis of tumour development. J Pathol. 2005;205:130-44.

5. Moon RT, Kohn AD, De Ferrari GV, Kaykas A. WNT and $\beta$-catenin signaling: disease and therapies. Nat Rev Genet. 2004;5:691-701.

6. Ben-Ze'ev A, Geiger B. Differential molecular interaction of $\beta$-catenin and plakoglobulin in adhesion, signaling and cancer. Curr Opin Cell Biol. 1998;10:629-39.

7. Prognostic significance of CyclinD1 and E-Cadherin in patients with esophageal squamous cell carcinoma: multiinstitutional retrospective analysis. Research Committee on Malignancy of Esophageal Cancer, Japanese Society for Esophageal Diseases. J Am Coll Surg. 2001;192: 708-18.

8. Conacci-Sorrell M, Zhurinsky J, Ben-Ze'ev A. The cadherin-catenin adhesion system in signaling and cancer. J Clin Invest. 2002;109:987-91.

9. Brembeck FH, Rosario M, Birchmeier W. Balancing cell adhesion and Wnt signaling, the key role of $\beta$-catenin. Curr Opin Genet Dev. 2006;16: 51-9.

10. Damalas A, Ben-Ze'ev A, Simcha I, Shtutman M, Leal JF, Zhurinsjy J, et al. Excess $\beta$-catenin promotes accumulation of transcriptionally active p53. EMBO J. 1999; 18:3054-63.

11. Harris SL, Levine AJ. The p53 pathway: positive and negative feedback loops. Oncogene. 2005;24:2899-908.

12. Levine AJ. p53, the cellular gatekeeper for growth and division. Cell. 1997;88:323-31.

13. Iwai A, Marusawa H, Matsuzawa S, Fukushima T, Hijikata M, Reed JC, et al. Siah-1L, a novel transcript variant belonging to the human Siah family of proteins, regulates $\beta$-catenin activity in a p53-dependent manner. Oncogene. 2004;23:7593-600.

14. Levina E, Oren M, Ben-Ze'ev A. Downregulation of $\beta$-catenin by p53 involves changes in the rate of $\beta$-catenin phosphorylation and Axin dynamics. Oncogene. 2004;23:4444-53.

15. Sadot E, Geiger B, Oren M, Ben-Ze'ev A. Down-regulation of ß-catenin by activated p53. Mol Cell Biol. 2001;21:6768-81.

16. Greene FL, Page DL, Fleming ID, Fritz AG, Balch CM, Haller DG, et al. AJCC Cancer Staging Manual. 6th ed. New York: Springer-Verlag; 2002.

17. de Castro J, Gamallo C, Palacios J, Moreno-Bueno G, Rodriguez N, Feliu $\mathrm{J}$, et al. $\beta$-catenin expression pattern in primary oesophagea squamous cell carcinoma. Relationship with clinicopathologic features and clinical outcome. Virchows Arch. 2000;437:599-604.

18. Nair KS, Naidoo R, Chetty R. Microsatellite analysis of the APC gene and immunoexpression of E-cadherin, catenin, and tubulin in esophageal squamous cell carcinoma. Hum Pathol. 2006;37:125-34.

19. Takayama T, Shiozaki H, Shibamoto S, Oka H, Kimura Y, Tamura S, et al. $\beta$-catenin expression in human cancers. Am J Pathol. 1996;148. 39-46.

20. Nakanishi Y, Ochiai A, Akimoto S, Kato H, Watanabe H, Tachimori Y, et al. Expression of E-cadherin, $\alpha$-catenin, $\beta$-catenin and plakoglobin in esophageal carcinomas and its prognostic significance: immunohistochemical analysis of 96 lesions. Oncology. 1997;54:158-65.

21. Takayama N, Arima S, Haraoka S, Kotho T, Futami K, Iwashita A. Relationship between the expression of adhesion molecules in primary esophageal squamous cell carcinoma and metastatic lymph nodes. Anticancer Res. 2003;23:4435-42.

22. Zhao XJ, Li H, Chen H, Liu YX, Zhang LH, Liu SX, et al. Expression of E-cadherin and $\beta$-catenin in human esophageal squamous cell carcinoma: relationships with prognosis. World J Gastroenterol. 2003 9:225-32. 
23. Kang Y, Massague J. Epithelial-mesenchymal transitions: twist in development and metastasis. Cell. 2004;118:277-9.

24. Thiery JP. Epithelial-mesenchymal transitions in tumor progression. Nat Rev Cancer. 2002;2:442-54.

25. Nair KS, Naidoo R, Chetty R. Expression of cell adhesion molecules in esophageal carcinoma and its prognostic value. J Clin Pathol. 2005;58: 343-51.

26. Zhang G, Zhou X, Xue L, Quan L, Wang Y, Zhou C, et al. Accumulation of cytoplasmic $\beta$-catenin correlates with reduced expression of E-cadherin, but not with phosphorylated Akt in esophageal squamous cell carcinoma: immunohistochemical study. Pathol Int. 2005;55:310-7.

27. Shiozaki H, Doki Y, Kawanishi K, Shamma A, Yano M, Inoue M, et al. Clinical application of malignancy potential grading as a prognostic factor of human esophageal cancers. Surgery. 2000; 127:552-61.

28. Yamaguchi M, Hirose F, Inoue YH, Ohno K, Yoshida H, Hayashi Y, et al. Genetic link between $\mathrm{p} 53$ and genes required for formation of the zonula adherens junction. Cancer Sci. 2004;95:436-41.

29. Torbenson M, Kannangai R, Abraham S, Sahin F, Choti M, Wang J. Concurrent evaluation of $\mathrm{p} 53, \beta$-catenin, and $\alpha$-fetoprotein expression in human hepatocellular carcinoma. Am J Clin Pathol. 2004;122: 377-82.

30. Nozawa N, Hashimoto S, Nakashima Y, Matsuo Y, Koga T, Sugio K, et al. Immunohistochemical $\alpha$ - and $\beta$-catenin and E-cadherin expression and their clinicopathological significance in human lung adenocarcinoma. Pathol Res Pract. 2006;202:639-50.

Access to The Journal of Thoracic and Cardiovascular Surgery Online is reserved for print subscribers!

Full-text access to The Journal of Thoracic and Cardiovascular Surgery Online is available for all print subscribers. To activate your individual online subscription, please visit The Journal of Thoracic and Cardiovascular Surgery Online, point your browser to http://www.mosby.com/jtcvs, follow the prompts to activate your online access, and follow the instructions. To activate your account, you will need your subscriber account number, which you can find on your mailing label (note: the number of digits in your subscriber account number varies from 6 to 10). See the example below in which the subscriber account number has been circled:

\section{Sample mailing label}

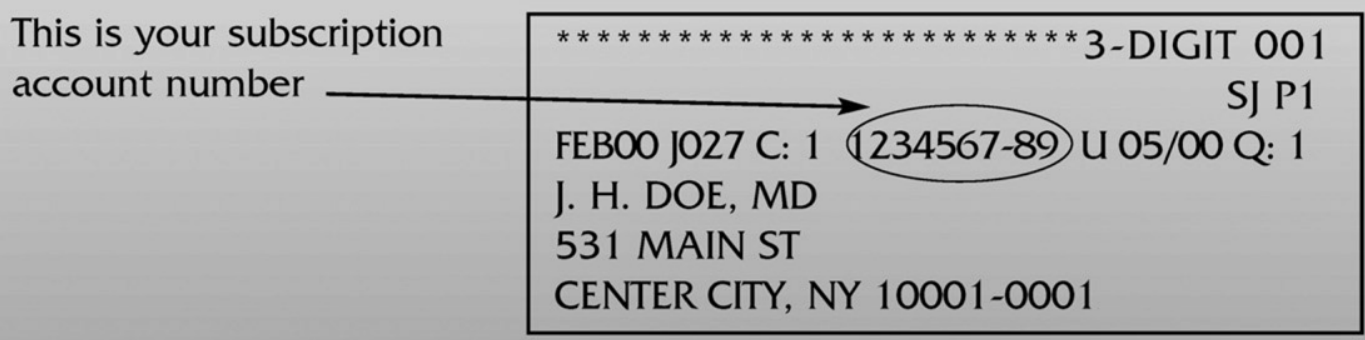

Personal subscriptions to The Journal of Thoracic and Cardiovascular Surgery Online are for individual use only and may not be transferred. Use of The Journal of Thoracic and Cardiovascular Surgery Online is subject to agreement to the terms and conditions as indicated online. 